ACTA THERIOLOGICA

Vol. 29, 26: 305-316, 1984

\title{
Breeding Parameters in the Bank Vole of Different Esterase Phenotypes
}

\author{
Anna M. WÓJCIK \& Stanisław FEDYK
}

\begin{abstract}
Wójcik A. M. \& Fedyk S., 1984: Breeding parameters in the bank vole of different esterase phenotypes. Acta theriol., 29, 26: 305-316, [With 5 Tables \& 1 Fig.]

Electrophoretic examination was made of the non-specific esterases of blood plasma in the inbred bank vole ( $\mathrm{sib}$ mating). One variable system of esterases (Es-7) controlled by two alleles at a single locus was chosen for this purpose. In the whole sample of 64 pairs examined $(\mathrm{n}=128) E s-7 \mathrm{~F}$ allele frequency was 0.65 , and $E s-7 \mathrm{~s} 0.35$. One of the alleles $(E s-7 \mathrm{~F})$ was more frequent in males, and the other $(E s-7 \mathrm{~s})$ in females. A relation was found in the bank vole between the phenotype of esterase Es-7 and the fertility of females and viability of their offspring. Heterozygotic females were more fertile and reared their young better, while heterozygotic offspring were distinguished by better survival than homozygotic offspring. It follows from this that heterozygotes in respect of Es-7 locus possessed a higher adaptive value under laboratory breeding conditions.
\end{abstract}

[Mammals Res. Inst., Polish Acad. Sci., 17-230 Białowieża, Poland]

\section{INTRODUCTION}

The great genetic variation of proteins revealed by the electrophoretic method must create balanced polymorphism in natural populations. It must be assumed that if biochemical polymorphism is maintained in natural populations (Petras, 1965; Selander, 1969, 1971; Smith et al., 1973; Fedyk \& Gębczyński, 1980; Bowen, 1982 and others) individuals which are carriers of alternative alleles must differ as to fertility or survival under varied conditions. There are, however, no studies endeavouring to penetrate into the nature itself of the phenomenon, and therefore all information serving to elucidate the whole complexity of the phenomenon of polymorphism in natural populations is of importance. In some studies the polymorphic system of proteins has been connected with breeding parameters and the viability of animals (Gaines \& Krebs, 1971; Tamarin \& Kohn, 1977).

The present paper forms an attempt at relating significant elements of the adaptive value of animals: fertility and viability with a selected biochemical' marker, blood plasma esterase. 


\section{MATERIAL AND METHODS}

The bank voles, Clethrionomys glareolus (Schreber, 1780) were obtained from inbreeding (sib mating) in the Mammals Research Institute, Polish Academy of Sciences at Białowieża. Breeding conditions (breeding rooms, food, temperature, illumination) and breeding parameters of outbred bank voles from 1956-1966 have been described by Buchalczyk (1970). The animals were mated at the age of 3-5 months. The studies were made on 64 pairs from generations from 14 to 21 . The majority of the pairs used for the experiment originated from generations 16, 17 and 18. It proved possible to establish relationship (parents-offspring) for part of the study material by means of breeding records. This was later used to trace inheritance of esterases.

Blood was sampled in vivo from the tail to a heparinized hematocrit capillary and centrifuged at $13,000 / \mathrm{min}$. After centrifuging, the capillary was cut through at the place of contact between plasma-erythrocytes then pieces of filter paper (Whatman 3) were saturated with plasma and electrophoretic separation carried out directly on starch gel in the horizontal system. A lithium hydroxide buffer after Selander et al. (1971) was used for gel and electrodes. 13\% starch gel hydrolyzed in our own laboratory was used. Electrophoresis lasted 17 hours (until the borate line reached the anodal sponge) with tension of $300 \mathrm{~V}$ for $30 \mathrm{~min}$., after which the filter papers were removed and tension increased to $350 \mathrm{~V}$. Intensity was about $10 \mathrm{~mA}$.

Plasma esterase were stained in two parallel ways: after Selander et al. (1971), using as substrate and staining agent: $\alpha$-naphtyl butyrate and Fast Blue RR, and after Harris \& Hopkinson (1970) using $\alpha$-naphtyl acetate and Fast Red TR. Eserine was used as inhibitor, with a concentration of $10^{-5} \mathrm{M}$.

In order to ensure certain and accurate identification of the phenotypes of the analyzed system of esterases, two identical standard plasmas were placed on each gel. These standards were obtained from a group of anaesthetized animals frum which a larger amount of blood was sampled and plasma stored at $-18^{\circ} \mathrm{C}$.

\section{RESULTS}

\subsection{Patterns of Esterases}

Nine systems of esterase activity bands were found in the plasma of the bank vole (Fig. 1). Two main most deeply staining systems of bands, appearing during the first minutes of staining, occurred in all the individuals: the monomorphic system of esterase activity in the albumin region (band 1 and 2) and a slow, polymorphic system (band 7). Band 1 occurred only on gels treated with $\alpha$-naphtyl acetate, and bands 1 and 2 on gels with $\alpha$-naphtyl butyrate. Bands 3 and 4 stained faintly and did not exhibit variation. In the region of band 5 considerable differences were observed in enzymatic activity, estimated optically on the basis of intensity of staining. This system exhibited polymorphism, but the 
patterns of the bands were unclear and it proved impossible to establish their inheritance. Bands 6 and 9 did not appear in all individuals.

The system of band 7 exhibited the greatest variation and intensity of staining in reactions with both substrates. Three types of band 7 were observed differing as to mobility, width and intensity of staining (Fig. 1). Two narrower and more deeply stained bands fast and slow, were considered to be homozygotes, and the wider, with intermediate mobility and staining intensity, as a heterozygote. These identifications were accepted on the basis of analysis of the phenotypes of parents and offspring (Table 1). The analysis showed that this esterase is under the control of two alleles at a single locus. Mating of homozygotic phenotype individuals produced offspring with identical phenotypes. The other combinations of matings also failed to exhibit deviations from the expected values, on the basis of the rule of allele segregation at a single locus. This locus was termed $E s-7$, and allele $E s-7 \mathrm{~F}$ and $E s-7 \mathrm{~s}$ were further defined respectively as allele $\mathrm{F}$ and allele $\mathrm{S}$.

Table 1

Segregation at the Es-7 locus in the bank vole.

\begin{tabular}{lcccc}
\hline \multirow{2}{*}{$\begin{array}{l}\text { Phenotype } \\
\text { of parents }\end{array}$} & $\begin{array}{c}\text { No. of } \\
\text { matings }\end{array}$ & \multicolumn{2}{c}{ No. of offspring of different phenotypes } \\
\cline { 3 - 5 } & 2 & FF & FS & SS \\
\hline FF $\times$ FF & 7 & 10 & - & - \\
FF $\times$ FS & 3 & 14 & 14 & - \\
FF $\times$ SS & 6 & $-8^{1}$ & 10 & - \\
FS $\times$ FS & 1 & - & 2 & - \\
FS $\times S S$ & 2 & - & - & 4 \\
SS $\times$ SS & & & & \\
\hline
\end{tabular}

$\chi^{2}=1.542 ; \quad 0.2<P<0.3$

Band 8 , partially coinciding with the band 7 system, was inhibited with eserine, from which it may be concluded that it probably corresponds to another esterase. It occurred below band 7 of homozygote $\mathrm{FF}$, but was not visible in the case of phenotypes FS and SS (Fig. 1).

\subsection{Phenotypes of Esterase Es-7 and Reproductivity of the Bank Vole and Viability of Offspring}

Heterozygotes $(n=58)$ and homozygotes FF $(n=51)$ were most numerously represented in the whole group of males and females examined. Homozygotes SS $(n=19)$ formed the smallest fraction. In this sample the mean frequency of allele $F$ was $q=0.65$ and correspondingly of allele $\mathrm{S}, \mathrm{q}=0.35$ (Table 2).

Statistically significant differences (over $10 \%$ ) were, however, observ- 


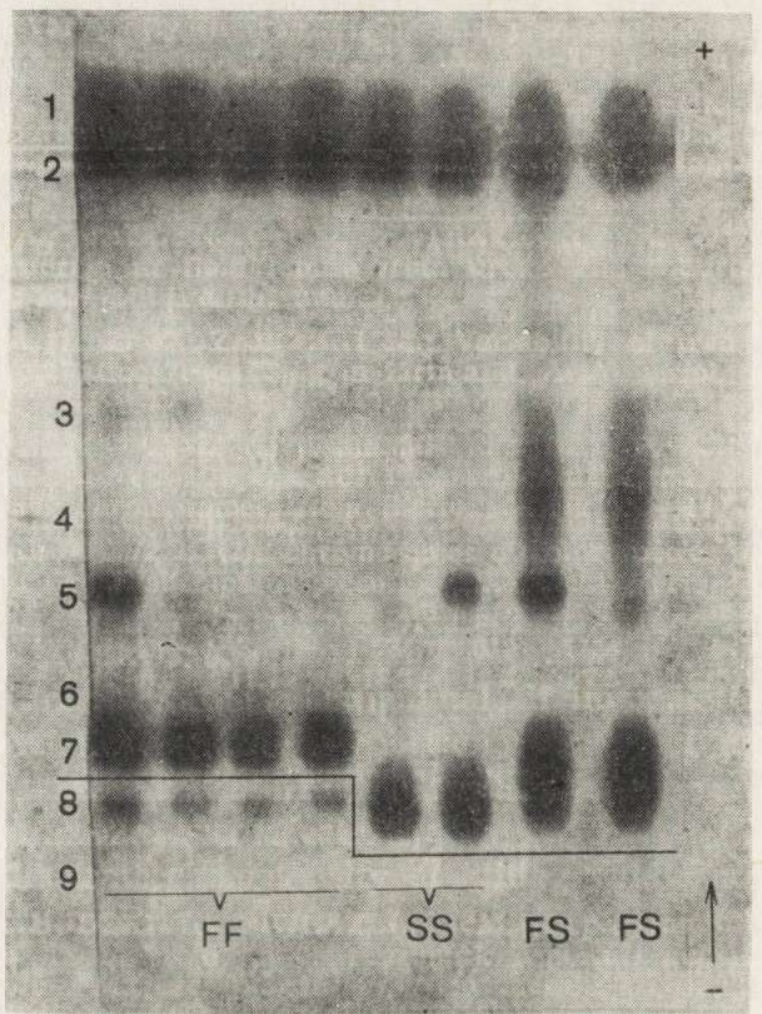

Fig. 1. Pattern of blood plasma esterase bands in the bank vole on gel staining with $\alpha$-naphtyl butyrate and Fast Blue RR. Phenotypes Es-7 indicated by symbols FF, FS, SS.

ed in frequency of alleles $\mathrm{F}$ and $\mathrm{S}$ in relation to sex. Allele $\mathrm{F}$ was more frequent in males than in females (Table 2).

All the pairs examined were divided into 9 types of mating, in which certain breeding parameters were studied: the number of litters born, the sum total of young born and weaned and size of litters born and weaned. In order to eliminate the influence of the parents' length of life on breeding indices, the period of the first 100 days from time of

Table 2

Number of Es-7 phenotypes and frequency of alleles $F$ and $S$ in males and females combined in pairs $(n=128)$. Using chi-square test calculation was made of the significance of differences in frequency of allele $\mathrm{F}$ between sexes.

\begin{tabular}{lccccccc}
\hline & FF & FS & SS & F & S & $\chi^{2}$ & P \\
\hline Females & 20 & 32 & 12 & 0.56 & 0.44 & 4.2000 & $<0.05$ \\
Males & 31 & 26 & 7 & 0.69 & 0.31 & & \\
Total & 51 & 58 & 19 & 0.65 & 0.35 & & \\
\hline
\end{tabular}




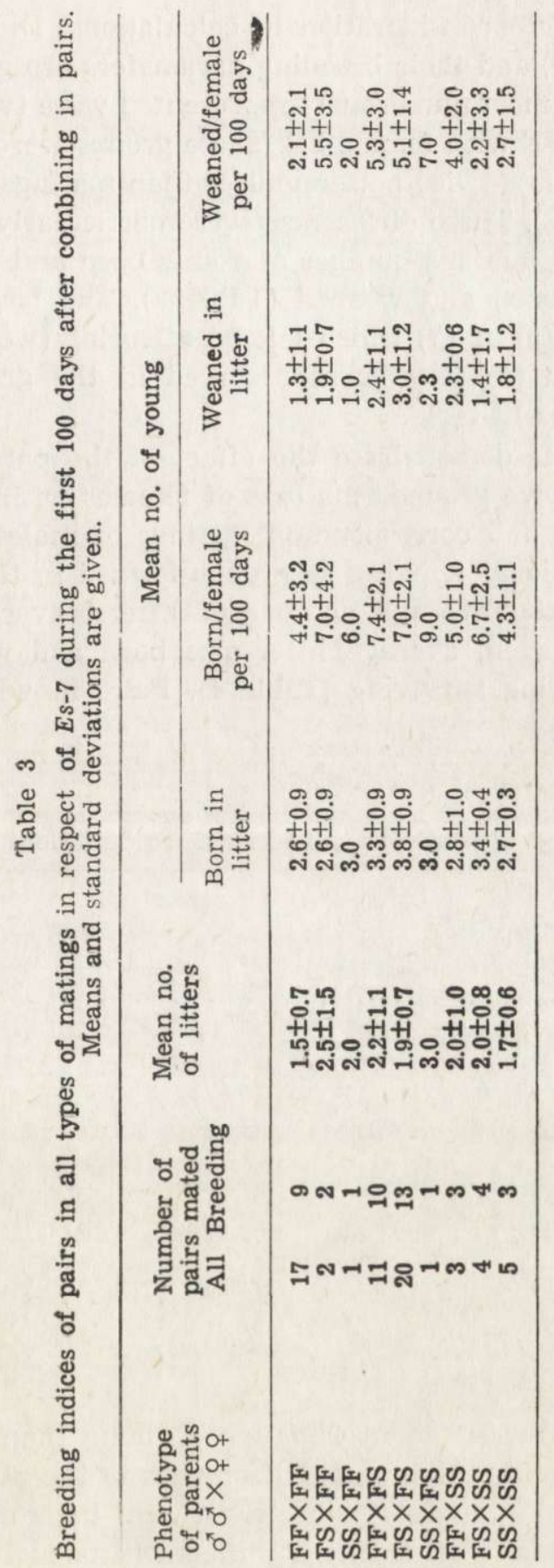


mating was taken into consideration in calculations. During this period 46 pairs were fertile, and their breeding parameters are given in Table 3 . The types of mating most numerously represented were two heterozygotes (FS $\times$ FS) and male FF with female FS. These groups were simultaneously distinguished by almost twice better indices than matings of homozygotes ( FF $\times$ FF and SS $\times$ SS). These differences were particularly clearly evident in comparison of the average number of young born and weaned and the average litter size born and weaned (Table 3). The largest number of pairs (10 out of a total of 17) which left no offspring (were either sterile or did not rear the progeny born) occurred in the group of matings between homozygotes $\mathrm{FF} \times \mathrm{FF}$.

In order to better demonstrate the effect of the parents' phenotype on breeding indices, we grouped matings of females with FF, FS and SS with optional males and corresponding matings of males with different phenotypes with optional females. In groups formed in this way calculation was made of the average number of litters, average number of young born and weaned, average litter size born and weaned and the percentage of offspring surviving (Table 4). Pairs in which the female

Table 4

The effect of the phenotype of male and female on breeding indices in the bank vole (explanation in text). Means and standard deviations are given.

\begin{tabular}{lccccccc}
\hline & \multicolumn{3}{c}{ Males } & & \multicolumn{3}{c}{ Females } \\
\cline { 2 - 3 } & FF & FS & SS & & FF & FS & SS \\
\hline $\begin{array}{l}\text { No. of } \\
\text { matings }\end{array}$ & 22 & 19 & 5 & 12 & 24 & 10 \\
$\begin{array}{l}\text { No. of } \\
\text { litters }\end{array}$ & $1.9 \pm 1.0$ & $2.0 \pm 0.7$ & $2.0 \pm 0.7$ & $1.7 \pm 0.7$ & $2.1 \pm 0.9$ & $1.9 \pm 0.7$ \\
$\begin{array}{l}\text { No. of young } \\
\text { in litter }\end{array}$ & $3.0 \pm 0.9$ & $3.6 \pm 0.9$ & $2.8 \pm 0.3$ & $2.6 \pm 0.8$ & $3.6 \pm 0.9$ & $3.0 \pm 0.7$ \\
$\begin{array}{l}\text { No. of young } \\
\text { born/female }\end{array}$ & $5.9 \pm 3.7$ & $6.9 \pm 2.3$ & $5.6 \pm 2.2$ & & $5.0 \pm 3.2$ & $7.3 \pm 3.1$ & $5.5 \pm 1.9$ \\
$\begin{array}{l}\text { No. of young } \\
\text { weaned/litter }\end{array}$ & $1.9 \pm 1.1$ & $2.5 \pm 1.4$ & $2.0 \pm 1.3$ & $1.4 \pm 1.0$ & $2.7 \pm 1.1$ & $1.8 \pm 1.2$ \\
$\begin{array}{l}\text { No. of young } \\
\text { weaned/female }\end{array}$ & $3.8 \pm 2.9$ & $4.5 \pm 2.3$ & $3.4 \pm 2.3$ & $2.7 \pm 2.5$ & $5.2 \pm 2.2$ & $2.9 \pm 2.4$ \\
$\begin{array}{l}\text { Per cent of } \\
\text { young weaned }\end{array}$ & 65.1 & 65.1 & 60.7 & & 53.3 & 72.4 & 52.7 \\
\hline
\end{tabular}

was a heterozygote reared about $20 \%$ more young than in the case of matings with a homozygotic female. Differences in the number of young reared and the size of the reared litter between heterozygotic and homozygotic females were statistically significant (Student $t$ test, $P<0.05$ ). When comparing breeding indices of pairs in which the female was one of the homozygotes, matings with female SS proved to be minimally 
better. The effect of the phenotype of the male on the number of young. reared was not, however, significant.

The viability of offspring was described by the number of young. surviving the period from birth to leaving their parents. Number of young reared depends on the properties of parents (especially mothers) as well as the properties of offspring which may be distinguished by lesser or greater viability. It is very difficult in practice to separate these two effects.

In the case of mating homozygotes (four combinations) the phenotypes of generation $\mathrm{F}_{1}$ may be determined without any doubt, but when heterozygotes are mated a ratio of $0.25: 0.50: 0.25$ (FF:FS : SS) is to be expected. In the remaining four combinations of mating heterozygotes with homozygotes, after allowing for the number of the different types. of matings, these proportions were established at $0.35: 0.50: 0.15$ (FF : :FS : SS). In the groups formed in this way calculation was made of the absolute number of young born and weaned and the percentage of young surviving (Table 5). The largest percentage of young surviving.

Table 5

Expected frequencies of phenotypes in generation $F_{1}$ and absolute numbers of offspring born and weaned also percentage of weaned young in five groups of matings (number of pairs of different types of mating is given in Table 4).

\begin{tabular}{|c|c|c|c|c|c|c|c|c|c|}
\hline \multirow{3}{*}{$\begin{array}{l}\text { Phenotype } \\
\text { of parents }\end{array}$} & \multirow{2}{*}{\multicolumn{3}{|c|}{$\begin{array}{l}\text { Expected frequencies } \\
\text { of given phenotypes } \\
\text { in } F_{1} \text { generation }\end{array}$}} & \multicolumn{6}{|c|}{ Number of offspring } \\
\hline & & & & \multicolumn{3}{|c|}{ For the whole life } & \multicolumn{3}{|c|}{ For the first 100 days } \\
\hline & $\mathrm{FF}$ & FS & SS & Born & Weaned & $\%$ & Born & Weaned & $\%$ \\
\hline \multirow{2}{*}{$\begin{array}{l}\mathrm{SS} \times \mathrm{SS} \\
\mathrm{FF} \times \mathrm{SS} \\
\mathrm{SS} \times \mathrm{FF}\end{array}$} & - & - & 1 & 43 & 22 & 51.2 & 13 & 8 & 61,5 \\
\hline & - & 1 & - & 59 & 47 & 79.7 & 20 & 14 & 70.0 \\
\hline $\mathrm{FF} \times \mathrm{FF}$ & 1 & - & - & 105 & 44 & 41.9 & 40 & 19 & 47.5 \\
\hline \multirow{2}{*}{$\begin{array}{l}\mathrm{FS} \times \mathrm{FS} \\
\mathrm{SS} \times \mathrm{FS}\end{array}$} & 0.25 & 0.50 & 0.25 & 192 & 143 & 74.5 & 91 & 66 & 72,5 \\
\hline & $0.35^{1}$ & $0.50^{1}$ & $0.15^{1}$ & 208 & 130 & 62.5 & 124 & 83 & 66.9 \\
\hline \multicolumn{10}{|l|}{$\mathrm{FS} \times \mathrm{SS}$} \\
\hline \multicolumn{10}{|l|}{$\mathrm{FS} \times \mathrm{FF}$} \\
\hline
\end{tabular}

1 Modified proportions after taking into account the number of pairs in the given tyre of matings.

the nest period occurs in heterozygotic offspring obtained from mating opposite homozygotes $(79.7 \%$ ) and among those born during the first 100 days $(70.0 \%)$, and in offspring obtained from mating heterozygotes $\left(74.5^{\circ} \%\right)$, and during the first hundred days $\left(72.5^{\circ} \%\right)$. It is only in the second case that it may be concluded that the female phenotype exerted a favourable influence on the total number of young reared, whereas in the first case it may be assumed that it is a case of heterosis. 


\section{DISCUSSION}

Non-specific esterases are enzymes often used to examine protein variation in populations of different animal species. The method for describing esterases has not yet, however, been unified and consequently it is difficult to compare the results of studies by different authors.

In general it has been found that non-specific esterases are highly polymorphic, and that different substrates and inhibitors must be used to reveal them in order to distinguish the substrate-active groups (Augustinsson, 1958; Holmes \& Masters, 1968).

The biological role of different forms of esterases in the animal organism has not as yet been completely determined. There are well-known papers (Stanisławska, 1981) demonstrating the physiological variation of plasma esterases in females during the period of gestation and lactation. Tegelström (1975) found that it is possible for several esterase bands to occur in the liver of laboratory mice as aggregates of lipoproteins, which dissociated into various active components under the action of detergents and lipase. Lipoproteins also occur in the blood plasma of mammals, playing the part of transporters of lipids and certain vitamins. It is possible that esterase $E s-7$ of the blood plasma in the bank vole is also an aggregate of lipoproteins compounded with globulin fractions.

Tegelström et al. (1975) consider, on the strength of their own studies and those of other authors that "studies of variation in the esterases must be combined with breeding data to establish that the variation is genetic". In our studies the choice of esterase Es-7 was dictated by technical considerations, i.e. the good legibility of bands and the possibility of genetic interpretation confirmed by test matings (Table 1).

In the first description of electrophoretic variation in esterases of the bank vole in the Białowieża Primeval Forest 13 systems were distinguished, of which only four were from plasma and the remainder from liver homogenates and blood vessel hemolyzates (Fedyk \& Gębczyński, 1980). In the present study 9 systems of plasma esterases were distinguished, but without carrying out special comparative studies it is impossible to demonstrate homology of these systems (cf. Dawson, 1982). In the studies on a natural population of bank voles differentiation of heterozygosity was found between the spring and autumn seasons. It is certain that these differences are connected with the existence of balanced polymorphism in the bank vole, including a variety of polymorphic systems of proteins (Fedyk \& Gębczyński, 1980). Esterase polymorphism discovered by means of electrophoresis was connected with the organism's metabolism. In Apodemus sylvaticus it was found that individuals with higher metabolism survive the winter period best, this 
being connected with an excess of Es-2 heterozygotes in spring (Berry, 1979). It may be assumed that varying heterozygosity in autumn and winter in the bank vole (Fedyk \& Gębczyński, 1980) is also connected with differences in metabolism.

In the maijority of studies on variation of proteins in different animal species no significant differences have been found in allele frequencies between sexes. Berry (1981) in examining house mice from islands where the average temperature was $2{ }^{\circ} \mathrm{C}$ (stress habitat) showed that allele $E s-6^{\text {a }}$ occurred more frequently in adult males than in adult females, whereas the opposite situation prevailed in animals less than 3 months old. Similar variations were found in the case of Got-2 alleles. In the group of bank volles which we examined there were also significant differences (Table 2) in frequency of alleles between sexes. It must be remembered that breeding in captivity forms conditions not typical for these animals, which may affect allele frequency in both sexes.

In our studies we have shown that better fertility and viability indices in the bank vole are found for the period of nest life in heterozygotic individuals in respect of esterase Es-7. It would seem that in the case of locus of Es-7 heterozygotes have a higher adaptive value, which in consequence causes maintenance of both alleles in the study laboratory "population". This would be an example for an important model in population genetics, since selection favours heterozygotes and acts against both homozygotes (Krzanowska et al., 1982). The material used in these studies was obtained from inbreeding and not from a natural population crossbreeding more or less at random. When analyzing inbreeding, however, it is incorrect to overlook the effect of selection since even in a laboratory experiment it is impossible completely to avoid natural selection (Falconer, 1974).

In order to find "evidence for selective advantage of one allele over another" Ruddle \& Roderick (1968) examined variation of esterases Es-1 and $E s-3$ in four independent lines of laboratory mice. The lines were tested in 19 generations, two of the four stocks had been propagated by eight pair-matings per generation and two by 16 pairs. At the $E s-1$ locus only one stock was fixed and all stocks were segregating at the Es-3 locus. Selander et al. (1969) consider "Ruddle and Roderick's experimental material was unsuitable for demonstrating differences of any reasonable magnitude in selective values between alleles, because of the small effective size of these laboratory "populations" and the fact that only four lines were examined". In the case of the Es-7 locus examined it also proved impossible to find "evidence for selective advantage of one allele over another", since it was additionally shown that the adaptive value 
of heterozygotic individuals was higher, although with strict inbreeding random fixing of one of the alleles would probably take place.

It may be assumed that selection of an inbred line with $100 \%$ participation of one of the Es-7 alleles should bring about a decrease in the fertility of females and number of young reared during the nest period. Maintenance of constant balance between alleles $\mathrm{F}$ and $\mathrm{S}$ in Es-7 locus should give twice better breeding results than might have been expected from lines selected only for one of the alleles. It is of course obvious that such characters as fertility and viability of animals are affected by a large number of genetic and habitat factors. In the case described by us Es-7 locus undoubtedly acts in combination with other loci.

It would be useful to check if bank voles with different phenotypes of esterase Es-7, living under natural conditions, differ in respect of fertility and viability of offspring, and whether differences in frequency of alleles between sexes are confirmed.

Acknowledgements: Our thanks are due to Dr. M. Gębczyński for his generous help and critical reading of the first draft of this paper, and also to Dr. J. Rafiński for critical comments on the manuscript and to Mrs J. Lipińska for her technical assistance.

\section{REFERENCES}

1. Augustinsson K.-B., 1958: Electrophoretic separation and classification of blood plasma esterases. Nature, 181: 1786-1789.

2. Berry R. J., 1970: Covert and overt variation, as exemplified by british mouse populations. Symp. zool. Soc. Lond., 26: 3-26.

3. Berry R. J., 1981: Town mouse, country mouse: adaptation and adaptability in Mus domesticus (M. musculus domesticus). Mammal Review, 11: 91-136.

4. Bowen B. S., 1982: Temporal dynamics of microgeographic structure of genetic variation in Microtus californicus. J. Mammal., 63: 625-638.

5. Buchalczyk A., 1970: Reproduction, mortality and longevity of the bank vole under laboratory conditions. Acta theriol., 15: 154-176.

6. Dawson W. D., 1982: Protein polymorphisms in American deermice (Peromyscus) and genetic linkage homology. Acta theriol., 27: 213-230.

7. Falconer D. S., 1974: Dziedziczenie cech ilościowych. PWN: 1-392. Warszawa.

8. Fedyk A. \& Gębczyński M., 1980: Genetic changes in seasonal generations of the bank vole. Acta theriol., 25: 475-485.

9. Gaines M. S. \& Krebs Ch. J., 1971: Genetic changes in fluctuating vole populations. Evolution, 25: 702-723.

10. Harris H. \& Hopkinson D. A., 1976: Handbook of enzyme electrophoresis in human genetics. North- Holland Publ. Co.: 1-200. Amsterdam,

11. Holmes R. S. \& Masters J., 1968: A comparative study of the multiplicity of mammalian esterases. Biochim. Biophys. Acta, 151: 147-158.

12. Kohn P. H. \& Tamarin R. H., 1978: Selection at electrophoretic loci for reproductive parameters in island and mainland voles. Evolution, 32: 15-28. 
13. Krzanowska H., Łomnicki A. \& Rafiński J., 1982: Wprowadzenie do genetyki populacji. PWN: 1-224. Warszawa.

14. Petras M. L., 1967: Studies of natural populations of Mus. I. Biochemical polymorphisms and their bearing on breeding structure. Evolution, 21: 259-274.

15. Ruddle F. H. \& Roderick T. H., 1966: The genetic control of two types of esterases in inbred strains of the mouse. Genetics, 54: 191-202.

16. Selander R. K., Yang S. Y. \& Hunt G., 1969: XVI. Polymorphism in esterases and hemoglobin in wild populations of the house mouse (Mus musculus). Univ. Texas Studies in Genetics, V, 6918: 271-338.

17. Selander R. K., Smith M. H., Yang S. Y., Johnson W. E. \& Gentry J. B., 1971. Biochemical polymorphism and systematics in the genus Peromyscus. I. Variation in the old-field mouse (Peromyscus polionotus). Univ. Texas Studies in Genetics, 6: 49-90.

18. Smith M. H., Selander R. K. \& Johnson E. W., 1973: Biochemical polymorphism and systematics in the genus Peromyscus. III. Variation in the Florida deer mouse (Peromyscus floridanus), a Pleistocene relict. J. Mamm., 54: 1-13.

19. Stanisławska B., 1981: Rozdziały na żelu skrobiowym białek osocza i esteraz osoczowych u lisic polarnych w czasie ciąży i laktacji. Medycyna Wet., 37: $246-249$

20. Tegelström H., 1975: Liver esterases of the house mouse (Mus musculus L.) Characterization, efects of detergents and possible aggregation of non-specific esterases into macromolecular complex. Comp. Biochem. Physiol., 50B: 177-187.

21. Tegelström H., Haggström A. \& Kvassman S., 1975: Esterases of the snails Helix pomatia and Cepaea hortensis. Variation and characterization of different molecular forms. Hereditas, 79: 117-124.

Accepted, May 15, 1984.

Anna M. WÓJCIK i Stanisław FEDYK

\section{WSKAŹNIKI ROZRODU NORNICY RUDEJ O ROŻNYCH FENOTYPACH ESTERAZY OSOCZA KRWI}

\section{Streszczenie}

Metodą elektroforezy na żelu skrobiowym badano esterazy osocza krwi u 64 par $(\mathrm{n}=128)$ nornic rudych pochodzących $\mathrm{z}$ hodowli wsobnej (kojarzenie brata $\mathrm{z}$ siostra). W osoczu nornicy rudej stwierdzono co najmniej 9 esterazowych systemów prążków (Ryc. 1), z których najbardziej zmienny był system (Es-7) o małej ruchliwości elektroforetycznej. Opisano trzy fenotyp̣y tej esterazy, różniące się ruchliwością elektroforetyczną, szerokością prążków i intensywnością zabarwienia. Na podstawie analizy fenotypów rodziców i potomstwa stwierdzono, że esteraza ta jest kontrolowana przez jeden locus z dwoma allelami: Es-7F i Es-7s (Tabela 1). W całej próbie frekwencja allelu Es-7F wynosiła 0.65 , a Es-7s 0.35 . Zaobserwowano istotne różnice we frekwencji alleli $w$ odniesieniu do płci. Jeden $z$ alleli (Es-7F) był częstszy $u$ samców niż u samic (Tabela 2).

Wykazano istnienie zależności między fenotypem esterazy Es-7 a płodnością 
samic i żywotnością potomstwa w okresie gniazdowym u nornicy rudej. Wyróżniono 9 typów kojarzeń, u których badano niektóre wskaźniki rozrodu (ilość miotów, suma młodych urodzonych i odchowanych oraz wielkość miotu urodzonego i odchowanego) $\mathrm{w}$ okresie 100 pierwszych dni od momentu połączenia w parę (Tabela 3). Samice heterozygotyczne były płodniejsze i lepiej odchowywaly potomstwo (Tabela 4), a heterozygotyczne potomstwo odznaczało się lepszą żywotnością niż potomstwo homozygotoyczne (Tabela 5). Wynika z tego, że heterozygoty pod względem Es-7 mialy wyższą wartość przystosowawczą w warunkach hodowli laboratoryjnej. 